\title{
The results and reliability of ERCP due to choledocholithiasis at pregnancy: a case report and literature review
}

\author{
Betül Yorgunlar', Suna Özdemir ${ }^{1}$, Derya Uyan², Lebriz Hale Aktün Tamer ${ }^{1}$ \\ ${ }^{\prime}$ Department of Obstetrics and Gynecology, Faculty of Medicine, Istanbul Medipol University, Istanbul, Turkey \\ 2Obstetrics \& Gynecology Clinic, Acıbadem Atakent Hospital, Istanbul, Turkey
}

\begin{abstract}
Objective: Pregnancy is an important risk factor for growth of choledochal stones. Since choledocholithiasis encountered during pregnancy, which is also a possible cause of pancreatitis and cholangitis, may be the reason for serious morbidity and mortality both for the mother and the fetus, it should be treated. In this article, the results and reliability of endoscopic retrograde cholangiopancreatography (ERCP) application on a pregnant woman to whom ERPC is applied because of choledocholithiasis are presented.

Case: Patient who was 21 years old, giving two living births of three gravidas, applied in her 21 weeks of gestation with the complaints of nausea, vomiting and backache. After examinations, she was diagnosed as choledocholithiasis. The ERCP applied patient has delivered a healthy baby at term following a pregnancy with no problems.

Conclusion: ERCP is the first procedure that will be preferred in the treatment of choledocholithiasis in pregnancy with the right indications provided that proper precautions have been taken. Possible harmful effects of ionized radiation on fetus during fluoroscopy should be minimalized by giving in short periods and low doses.
\end{abstract}

Keywords: Pregnancy, choledocholithiasis, fluoroscopy.

\section{Introduction}

Pancreatobiliary diseases are seen relatively rare during pregnancy. Gallstone prevalence during pregnancy is about 3.3-12.2\%..$^{[1-3]}$ Physiological changes occurring during pregnancy tends to increase the gallstone forma-
Özet: Gebelikte koledokolitiyazis nedeniyle ERCP uygulamasının sonuçları ve güvenilirliği: Olgu sunumu ve literatürün gözden geçirilmesi

Amaç: Gebelik koledok taşlarının gelişimi için önemli bir risk faktörüdür. Gebelikte karşılaşılan koledokolitiyazis ve neden olabileceği pankreatit ve kolanjit, hem anne hem fetüs için ciddi morbidite ve mortalite nedeni olabileceğinden, mutlaka tedavi edilmelidir. Bu makalede, koledokolitiyazis nedeniyle endoskopik retrograd kolanjiyopankreatografi (ERCP) uygulanan bir gebede ERCP uygulamasının sonuçları ve güvenilirliği sunulmuştur.

Olgu: Yirmi bir yaşında, gravidası 3 yaşayanı 2 olan hasta, 21. gebelik haftasında bulantı, kusma ve sırt ağrısı şikayeti ile başvurdu. Yapılan tetkikler sonrası koledokolitiyazis tanısı konuldu. ERCP uygulanan hasta sorunsuz bir gebelik sonrası miadında sağlıklı bir bebek doğurdu.

Sonuç: Gebelikte koledokolitiyazis tedavisinde doğru endikasyonlarda ve uygun önlemler alınması şartıyla ERCP ilk tercih edilecek prosedürdür. Floroskopi sırasında verilen iyonize radyasyonun mümkün olduğunca düşük dozda ve kısa süreli verilerek fetüs üzerindeki olası zararlı etkileri azaltılmalıdır.

Anahtar sözcükler: Gebelik, koledokolitiyazis, floroskopi. causes cholangitis and gallstone pancreatitis or both and may lead to serious fatal results for mother and fetus, it should be treated. ${ }^{[4]}$ However, there are various difficulties in choledocholithiasis treatment during pregnancy.

Correspondence: Betül Yorgunlar, MD. Medipol Üniversitesi Tip Fakültesi, Kadın Hastalıkları ve Doğum Anabilim Dalı, İstanbul, Turkey.

e-mail: jindr_betul@yahoo.com

Received: March 3, 2014; Accepted: May 28, 2014
Available online at: www.perinataljournal.com/20140223008 doi: $10.2399 /$ prn. 14.0223008 QR (Quick Response) Code: 
The first option for gallstone treatment in non-pregnant women is surgical treatment. On the other hand, with additional problems such as general anesthesia being applied to patients during surgery at pregnancy and applying T-tube after choledochal exploration, surgery during pregnancy is not the first treatment option anymore. High fetal loss rates have been reported in the literature due to open cholecystectomy and choledochal examination during pregnancy. ${ }^{[5,6]}$ ERCP can be carried out safely during pregnancy providing that proper precautions are taken with right indications. However, there is a limited number of data in the literature and most of them are case reports.

In this study, we have presented the role and reliability of ERCP applied to a pregnant woman diagnosed as choledocholithiasis by reviewing the current literature data.

\section{Case Report}

Patient who was 21 years old, giving two living births of three gravidas, applied in her 21 weeks of gestation with the complaints of nausea, vomiting and back pain. In the physical examination, there were apparent jaundice in scleras and sensitivity in right bottom quadrant. In the obstetric ultrasonography, fetus with normal anatomy at 21 weeks of gestation coherent with last menstrual period was observed. The results obtained by laboratorial evaluation were as follows: hemoglobin: $12.7 \mathrm{~g} / \mathrm{dL}$, hematocrit: $37.1 \%$, thrombocyte: $24610^{\wedge} / \mathrm{uL}$, TSH: $1.73 \mathrm{uIU} / \mathrm{mL}$, AST: $152 \mathrm{U} / \mathrm{L}$, ALT: $169 \mathrm{U} / \mathrm{L}$, ALP: 418 U/L, LDH: 393 U/L, GGT: 34 U/L, total bilirubin: 2.2 $\mathrm{mg} / \mathrm{dL}$, indirect bilirubin: $0.98 \mathrm{mg} / \mathrm{dL}$, direct bilirubin: $1.22 \mathrm{mg} / \mathrm{dL}$. It was observed in the abdominal ultrasonography that liver size was within normal limits and gallbladder wall thickness and size were normal. There were sediment and milimetric stone echoes indicating interluminal leveling. Proximal choledochus was $19 \mathrm{~mm}$ and it was observed as wider than normal. No stone was found in the observable lumen. Slight dilatation was observed in intrahepatic bile ducts. The patient was established with choledocholithiasis diagnosis after these examinations, and ERCP was planned. For that purpose, the region was covered with protective apron in order to protect fetus in the operating room and it was entered to the second part of duodenum by videoduodenoscopy device (Olympus EVIS Exera TJF160VR; Olympus Medical Systems Corp., Tokyo, Japan) after premedica- tion by propofol. Ampulla region was in normal view when observed. Choledochus was canalized selectively. Choledochal intrahepatic bile ducts showed apparent dilatation in cholangiogram. Multiple stones were observed in choledochus. After the sphincterotomy, stones in choledoctus were moved by balloon and wiped to duodenum. No complication occurred during the procedure and it was observed in the follow-ups of the patient that nausea and vomiting complaints and jaundice in scleras regressed, and it was seen in the laboratory examinations that AST, ALT and bilirubin values returned to normal levels. No problem was observed in the antenatal examinations of the patient, and she delivered a healthy $4200 \mathrm{~g}$ male baby at term by cesarean section. No complication occurred in the postpartum follow-ups and the patient was discharged in health condition on second postoperative day.

\section{Discussion}

Endoscopic retrograde cholangiopancreatography (ERCP) is one of the main non-surgical procedures applied in the treatment for choledochal stones and gallstone pancreatitis. Since it has low rate of mortality and morbidity theoretically, ERCP is the first method to prefer in the treatment of cholangitis and pancreatitis due to choledocholithiasis during pregnancy. On the other hand, there are some limitations for applying ERCP. Endoscopic procedure and risks should be accepted by pregnant woman first. Also, ERCP indication should be established precisely, and it is significant to know at what trimester it will be done and at which position will she be during the procedure. Another significant factor limiting to carry out ERCP is that the ERCP is carried out in company with fluoroscopy, and therefore fetus is exposed to ionized radiation during the procedure.

The traditional treatment of choledocholithiasis is surgery. Due to the preterm labor and miscarriage found after surgical treatment, the treatment in pregnant women has been done conservatively. For example, fetal loss was reported in 5 out of 9 cases who underwent cholecystectomy and choledochus examinations. On the other hand, no increase was observed in the complication rates of cases who underwent laparoscopic surgery. ${ }^{[5,6]}$ In the study performed on 213 cases by Lachman et al., it was reported that laparoscopic cholecystectomy can be done safely during pregnancy. ${ }^{[7]}$ 
Using ERPC for removing symptomatic gallstones in the bile duct during pregnancy provides convenience ${ }^{[8]}$ However, as we mentioned above, the damage of ionized radiation on fetus is the major problem. IUGR, preterm labor, miscarriage, fetal malformations, fetal death, and childhood cancers were reported associated with the ionized radiation exposed during ERCP. Fetal damage associated with the radiation depends on the dose of radiation and the week of gestation. Due to this concern, there are many studies focused on fetal ionized radiation exposure by ERCP during pregnancy and on the fetal impacts of radiation. The study of Tham et al. found that 3.2 minutes of fluoroscopy and $301 \mathrm{mRad}$ fetal radiation exposure during ERCP were safe for mother and fetus. ${ }^{[9]}$ Although some studies reported that using lead vest decreases fetal exposure, it has not been proved in practice. ${ }^{[10]}$ While ACOG states that possible risks associated with radiation depend on radiation doses used at and above $5 \mathrm{Rad}$, it is recommended in diagnostic procedures during pregnancy to use ultrasonography and other imaging methods not including ionized radiation instead of those including ionized radiation. ${ }^{[1]}$

The study of Axelrad et al. suggests using fluoroscopic imaging methods by videoendoscopic system instead of using spot radiography. ${ }^{[12]}$ As it has been stated in many studies, it is possible to remove stones even in a single application by using fluoroscopy for a very short period. Llach et al. applied sphincterotomy by using ultrasonography in the first case and by no imaging method at second cases. ${ }^{[13]}$ The studies in the literature show that ERCP is a procedure applied safely even without fluoroscopy. ${ }^{[14,15]}$ Yet, there are no sufficient studies in this field. However, in the study of Jamidar et al., pancreatitis was reported only in one patient, spontaneous abortion only in one patient and neonatal death only in one patient. ${ }^{[2]}$ The study of García-Cano et al. from Spain was carried on a wide series of cases and the applications were performed in company with limited amount of flouroscopy. Lead vest was also used in these cases. In conclusion, no complication was observed in any of these pregnant women and all pregnancies reached to the term without any problem. ${ }^{[16]}$ In a case report in Turkey, ERCP was carried out with the help of magnetic resonance cholangiopancreatography (MRCP), and the procedure for removing endoscopic stones and cleaning bile duct were carried out without any fluoroscopy. ${ }^{[17]}$
When we compare MRCP and conventional cholangiography during pregnancy, we see that the most significant and only advantage of cholangiography is the possibility of real-time imaging. When we review the literature, we can see that the techniques such as biliary ductal cannulation together with ultrasound and echoultrasonography have been used recently in order to avoid fluoroscopy during ERCP. ${ }^{[18,19]}$

\section{Conclusion}

ERCP is the first procedure that will be preferred in the treatment of choledocholithiasis in pregnancy with the right indications provided that proper precautions have been taken. It is a safe and effective technique during pregnancy. However, there are some limitations such as fetal ionized radiation exposure. Noninvasive techniques such as MR and ultrasonography can also be referred. Possible harmful effects of ionized radiation on fetus during fluoroscopy should be minimalized by giving in short periods and low doses.

\section{Conflicts of Interest: No conflicts declared.}

\section{References}

1. Basso L, McCollum PT, Darling MR, Tocchi A, Tanner WA. A study of cholelithiasis during pregnancy and its relationship with age, parity, menarche, breast-feeding, dysmenorrhea, oral contraception and a maternal history of cholelithiasis. Surg Gynecol Obstet 1992;175:41-6.

2. Jamidar PA, Beck GJ, Hoffman BJ, Lehman GA, Hawes RH, Agrawal RM, et al. Endoscopic retrograde cholangiopancreatography in pregnancy. Am J Gastroenterol 1995;90:12637.

3. Swisher SG, Schmit PJ, Hunt KK, Hiyama DT, Bennion RS, Swisher EM, et al. Biliary disease during pregnancy. Am J Surg 1994;168:576-89.

4. Scott LD. Gallstone disease and pancreatitis in pregnancy.Gastroenterol Clin North Am 1992;21:803-15.

5. Sungler P, Heinerman PM, Steiner H, Waclawiczek HW, HolzingerJ, Mayer F, et al. Laparoscopic cholecystectomy and interventional endoscopy for gallstone complicacions during pregnancy. Surg Endosc 2000;14:67-71.

6. Glasgow RE, Visser BC, Harris HW, Patti MG, Kilpatrick SJ, Mulvihill SJ. Changing management of gallstone disease during pregnancy. Surg Endosc 1998;12:241-6.

7. Lachman E, Schienfeld A, Voss E, Gino G, Boldes R, Levine $\mathrm{S}$, et al. Pregnancy and laparoscopic surgery. J Am Assoc Gynecol Laparosc 1999;6:347-51.

8. Menees S, Elta G. Endoscopic retrograde cholangiopancreatography during pregnancy. Gastrointest Endosc Clin N Am 2006;16:41-57. 
9. Tham TC, Vandervoort J, Wong RC, Montes H, Roston AD, Slivka A, et al. Safety of ERCP during pregnancy. Am J Gastroenterol 2003;98:308-11.

10. Kahaleh M, Hartwell GD, Arseneau KO, Pejewski TN, Mullick T, Isin G, et al. Safety and efficacy of ERCP en pregnancy. Gastrointest Endosc 2004;60:287-92.

11. American College of Obstetricians and Gynecologists. Guidelines for diagnostic imaging during pregnancy. Int J Gynaecol Obstet 1995;51:288-91.

12. Axelrad AM, Fleischer DE, Strack LL, Benjamin SB, alKawas FH. Performance of ERCP for symptomatic choledocholithiasis during pregnancy: techniques to increase safety and improve patient management. Am J Gastroenterol 1994;89:109-12.

13. Llach J, Bordas JM, Ginès A, Mondelo F, Terés J. Endoscopic sphincterotomy in pregnancy. Endoscopy 1997; 29:52-3.

14. Simmons DC, Tarnasky PR, Rivera-Alsina ME, Lopez JF, Edman CD. Endoscopic retrograde cholangiopancreatogra- phy (ERCP) in pregnancy without the use of radiation. Am J Obstet Gynecol 2004;190:1467-9.

15. Shelton J, Linder JD, Rivera-Alsina ME, Tarnasky PR. Commitment, confirmation, and clearance: new tecniques for nonradiation ERCP during pregnancy. Gastrointest Endosc 2008;67:364-8.

16. García-Cano J, Pérez-Miranda M, Pérez-Roldán F, González-Carro P, González-Huix F, Rodríguez-Ramos C, et al. ERCP during pregnancy. Rev Esp Enferm Dig 2012;104: 53-8.

17. Bagcı S, Tuzun A, Erdil A, Gulsen M, Dagalp K. Treatment of choledocholithiasis in pregnancy: a case report Arch Gynecol Obstet 2003;267:239-41.

18. Oto A, Ernst R, Ghulmiyyah L, Hughes D, Saade G, Chaljub G. The role of MR cholagiography in the evaluation of pregnant patients with acute pancreatobiliary disease. Br J Radiol 2009;82:279-85.

19. Girotra M, Jani N. Role of endoscopic ultrasound/SpyScope in diagnosis and treatment of choledocholitiasis in pregnancy. World J Gastroenterol 2010;16:3601-2. 